Owczarczuk M., Transnational corporations in search of attractive institutional conditions in contemporary global economy, „Ekonomia i Prawo. Economics and Law.”, Polszakiewicz B., Boehlke J. (ed.), Vol. 13, No. 4/2014, pp. 533-544. DOI: http://dx.doi.org/10.12775/EiP.2014.038.

\title{
TRANSNATIONAL CORPORATIONS IN SEARCH OF ATTRACTIVE INSTITUTIONAL CONDITIONS IN CONTEMPORARY GLOBAL ECONOMY
}

\author{
SUMMARY
}

Transnational corporations (TNC) are important members of the global economy as they possess immense capital, productive, and technological potential, and involve a massive share of international economic relations. They are mainly responsible for the inflow of foreign direct investments and all their derivatives. Thanks to their power, TNCs are able to influence political decisions. When searching for locations for new investments, they choose places where they are met with the most favourable conditions. The 2007 financial crisis has significantly contributed to the reduction of international capital flow, effected mainly by TNCs. Such situation compelled various national economies to undertake actions which, on the one hand, ensured an attractive position for international investments, and, on the other hand, protected internal markets from speculative flows of capital.

The aim of this study was to present the changes which occurred after the last financial crisis in FDI flows throughout the global economy, focusing particularly on the economy of the EU. The analysis of the dynamics and structure of FDI flows has been performed in the context of introduced institutional changes established in the European Union after 2007. In this paper to a large extent were used materials developed by UNCTAD. The considerations set out in the article show that in recent

* Magdalena Owczarczuk, University of Bialystok, Faculty of Economics and Management, Department of Political Economy, ul. Warszawska 63, 15-062 Białystok, phone: +48 8574577 26, e-mail: m.owczarczuk@uwb.edu.pl. 
years, many countries have introduced favorable regulations for TNCs. These activities became an attempt to increase the investment attractiveness of the EU economies in times of reduced flows of foreign investment.

Keywords: Institutional changes, greenfield investments, cross-border M\&As, foreign direct investment, European Union

JEL classification: F21, F23, F55, K34

\section{INTRODUCTION}

Favourable changes in terms of foreign direct investments introduced by many countries as well as the high level of competitiveness between states have effected in similarities in the rules and conditions of conducting business by transnational corporations, mainly in highly developed economies. Moreover, the emergence of new players in the capital flow market, in the form of developing and transition economies, has made the fight for capital even fiercer. Therefore, governments today face a difficult problem in developing such instruments that would effectively impact the investment decisions of transnational corporations.

Undoubtedly, transnational corporations command impressive financial, technological, and intellectual assets. Their potential is further enhanced by their mobility, i.e. they are able to move their assets to locations where they can be most profitable. As a result, transnational corporations may freely select their localization, together with the legal system that regulates their activities.

The subject of the considerations that follow is the flow of direct foreign investments in today's global economy. Special focus is given to the activities of transnational corporations in European Union states, although their activity is restricted only to the direct investments they undertake. The study aims at presenting the changes which occurred after the last financial crisis in FDI flows, focusing particularly on the economy of the EU. The investigation revolves around the areas of institutional changes introduced by countries in this region after the perturbations in capital flow caused by the last crisis.

\section{TRANSNATIONAL CORPORATIONS' POTENTIAL IN THE GLOBAL ECONOMY}

Without a doubt, transnational corporations have a great influence on the dynamics of the contemporary global economy. In a network system of relations, the framework of corporations covers the flow of goods, services, infor- 
mation, and factors of productions. The basic forms of international expansion of TNCs include, in particular, investments in the shape of foreign direct investments, export of products and/or services, sale of licenses to foreign recipients, and alliances with other companies ${ }^{1}$. The field of activities of TNCs significantly expanded due to deregulations in financial markets and the liberalization of global capital flow. Companies more often decided to directly involve their capital and technology outside their countries of origin. Likewise, the expansion of transnational corporations was greatly influenced by the evolution of the relationship between corporations and states and the role they have played in making business activities international ${ }^{2}$. The reason for TNCs coming into position and power in international relations at the turn of the 21 st century lie also in the speeding scientific and technical revolution, which gave a new quality and speed to the processes occurring in global economy. Advanced technologies create favourable conditions for increasing the geographical range of corporations' activities, intensifying their activeness in the international environment. The digital revolution has also enabled previously unseen capacity for flexible organization of the process of production and integration of the research, production, and distribution phases in subsidiaries around the world ${ }^{3}$.

The potential of transnational corporations, warranting their position in the international environment, consists mainly of their relatively quickly growing number ${ }^{4}$, their scope of activities, impressive financial potential ${ }^{5}$ and

${ }^{1}$ M. Gasz, Znaczenie korporacji transnarodowych w gospodarce światowej, „Ekonomia i Prawo”, Vol. XI, No. 4/2012, p. 32.

${ }^{2}$ K. Piórko, "Wtadza” korporacji transnarodowych w stosunkach międzynarodowych, Wyd. Naukowe Grado, Toruń 2008, p. 44.

3 Ibidem, p. 42-43.

${ }^{4}$ For corporations, the turn of the 21st century was a period of a constant growth of their power. This is well reflected in the dynamic increase in the number of corporations from approximately 37,000 in 1990 , through 70,000 in 2004 , to more than 80,000 in 2008 . The increase of the number of foreign subsidiaries grew even more dynamically: in 1990 there were approximately 170,000 foreign branches, with 690,000 in 2004, and in 2008 their number exceeded 800,000. Source: UNCTAD, World Investment Report 1993. Transnational Corporations and Integrated International Production, United Nations, New York 1993, p. 22; UNCTAD, World Investment Report 2005. Transnational Corporations and the Internationalization of RED, United Nations, New York, Geneva 2005, p. 13; UNCTAD, World Investment Report 2009. Transnational Corporations, Agricultural Production and Development, United Nations, New York and Geneva 2009, p. 223

5 The total stock of foreign direct investments, which are the basis of international production of TNCs, exceeded USD 23 trillion in 2012. The sales in foreign subsidiaries in 2012 exceeded USD 25 trillion, of which USD 7.5 trillion accounted for export. Source: UNCTAD, 
high levels of technological innovativeness ${ }^{6}$, dominant share in the use intellectual capital and advances of the digital revolution.

Looking at numerous rankings based on various economic indicators, it is clear that the income of many corporations exceeds the GDP of certain countries. For example, based on income, the largest corporation (Royal Dutch Shell plc) ranked 23rd in global economies, followed by two other corporations. The scale of corporation's incomes is no longer comparable to incomes of small, poorly developed countries, but also to smaller, rich, European states. Among the countries which were below the 25th position are Austria, Denmark, Finland. Countries with GDPs just slightly greater than the income of Royal Dutch Shell include: Poland, Norway, Belgium, Sweden. The economic power transnational corporations is evident. By locating themselves in the place of their choosing, they are able to have talks with governments on an equal basis (although it is worth noting that it is not the country that chooses the corporation, but rather the corporation chooses the country ${ }^{7}$.

\section{CONTEMPORARY TENDENCIES OF TNC LOCALIZATION}

Global trends in international production are well reflected in the levels of internationalization of the biggest transnational corporations. Data for 100 largest TNCs, coming mainly from developed economies, show that in 2012 the internalisation of their activities slowed down. International sales of the top 100 transnational corporations decreased globally by $2.1 \%$ in 2012 , while their sales in domestic markets - most prominent in developed markets remained at a relatively stable level. A similar relationship is visible in the spheres of assets and employment. While employment and foreign assets remained almost unchanged compared to 2011, their domestic assets and employment increased by $5 \%$ and $6.8 \%$ respectively $^{8}$. This data shows that corporations from highly developed economies are focusing more and more on domestic production. Moreover, it must be emphasized that most mergers and

World Investment Report 2013. Global Value Chains: Investment and Trade for Development, United Nations, New York, Geneva 2013, p. 135.

${ }^{6}$ In 2011, research and development expenses of 1500 biggest international companies amounted to EUR 510.7 billion, which stands for more than half of the global R\&D expenditure.

${ }^{7}$ K. Bobińska, Od niekontrolowanej globalizacji do zinstytucjonalizowanej gospodarki światowej, Key Text, Instytut Nauk Ekonomicznych PAN, Warszawa 2009, p. 84.

${ }^{8}$ UNCTAD, World Investment Report 2013..., op. cit., p. 24-25. 
acquisitions made by 100 largest transnational corporation occurred in developed economies'.

The data for corporations originating from developing countries is completely different. 100 largest corporations from developing and transitions economies are fortifying their position in the global economy. Their involvement in global production is increasing: between 2001 and 2011, their share in foreign assets grew from $0.8 \%$ to $1.6 \%$, international sales increased from $0.9 \%$ to $5.9 \%$, and their employment rose from $1 \%$ to $8 \%$ in the same period. Most of the mergers and acquisitions conducted in 2011 by corporations from developing and transition countries also took place in economies in development or transition. This group of countries is also the recipient of the largest number of greenfield projects, executed by the biggest TNC, as well as TNC from developing countries ${ }^{10}$.

Figure 1. Share of FDI flows components by regions in global economy (millions of USD)

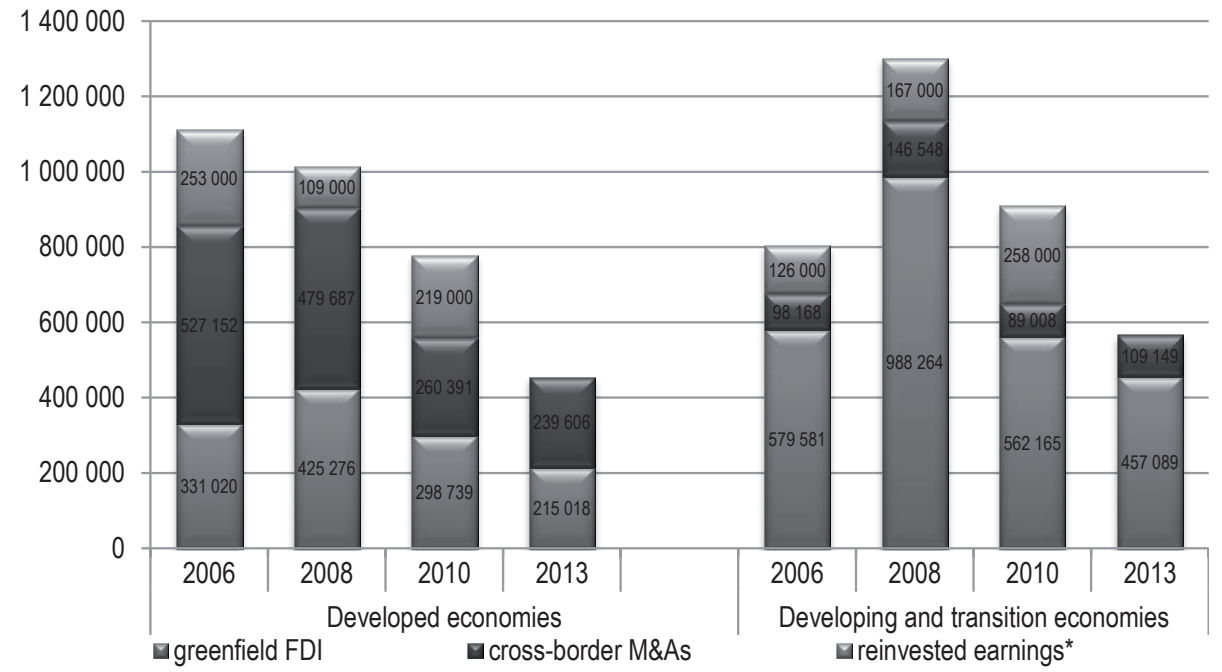

* data not available for 2013

Source: UNCTAD, World Investment Report 2013. Global Value Chains: Investment and Trade for Development, United Nations, New York, Geneva 2013, p. 34; UNCTAD, World Investment Report 2014. Investing in the SDGs: An Action Plan, United Nations, New York, Geneva 2014, p. 213-221.

${ }^{9}$ In 2012 transnational corporations conducted more than 300 mergers and acquisitions in developed countries, against fewer than 100 such transactions in developing and transition economies.

${ }^{10}$ UNCTAD, World Investment Report 2013..., op. cit., p. 23-24. 
Transnational ccorporations can take both direct and indirect (portfolio) investment. Foreign direct investment consist of: greenfield investments, cross-border mergers and acquisitions (M\&As), reinvested earnings and other capital flows (e.g. intra-company loans). Figure 1 illustrate the most important components of FDI flows. The largest value of greenfield projects falls for 2008 (more than 1,582 billion USD), yet that year also saw the lowest involvement of well developed countries in the inflow of such projects (less than 30\%). In the analyzed period, the variation in the inflow of this form of capital into developed countries was higher than that of developing countries. A large part of cross-border M\&As falls to the developed countries. Developed-country TNCs continued to hold large amounts of cash reserves in their foreign affiliates as a retained earnings, which constitute part of reinvested earnings. In 2013 this component reached a level of 67 per cent share of total capital flows in selected developed countries ${ }^{11}$.

\section{INSTITUTIONAL CHANGES IN SELECTED EUROPEAN UNION STATES AND THE INFLOW OF DIRECT INVESTMENTS}

Various factors decide on the location for investments by TNCs. The most important determinants are mainly the economic properties of a given territory (e.g., market size, growth potential, infrastructure, availability of labour resources), as well as legal and institutional conditions (for example, regulations for foreign capital businesses, costs of conducting business activities, existing trade agreements, property rights, including intellectual property rights, etc.). Numerous studies confirm, however, that foreign entrepreneurs have various motivations when choosing the location for their investments. The main motive depends on the investment strategy of a given TNC, that is, it depends on whether the investments a corporation carries out are more characterised by searching for a market or, rather, relatively low production costs ${ }^{12}$.

As UNCTAD data shows (collected in table 1), the European Union today is less interesting for investors than it was before the crisis. Participation of the European Union in global capital flows decreased dramatically. In 2013, the value of greenfield investments in EU amounted to USD 121,601 mil-

${ }_{11}$ UNCTAD, World Investment Report 2014. Investing in the SDGs: An Action Plan, United Nations, New York, Geneva 2014, p. 5-6.

${ }_{12}$ M. Kluzek, Znaczenie konkurencji podatkowej dla rozmieszczenia bezpośrednich inwestycji zagranicznych w Unii Europejskiej, Wydawnictwo Uniwersytetu Ekonomicznego w Poznaniu, Poznań 2012, p. 179. 
lion, only $18 \%$ share of the global inflow of such investments. This share decreased by 7 percentage points in comparison to 2007. EU countries noted a greater share in the mergers and acquisitions, but a decrease of this share was even stronger (16 percentage points). Negative dynamics of the inflows of both greenfield investments and cross-border M\&As into the EU dominated in the years 2007-2013 (except 2008 and 2011).

Table 1. Foreign direct investment in the European Union

\begin{tabular}{|c|c|c|c|c|c|c|c|}
\hline & 2007 & 2008 & 2009 & 2010 & 2011 & 2012 & 2013 \\
\hline \multicolumn{8}{|c|}{ FDI inflows by economy (mln USD) } \\
\hline World & 2002695 & 1818834 & 1221840 & 1422255 & 1700082 & 1330273 & 1451965 \\
\hline European Union & 859118 & 551413 & 363133 & 383703 & 490427 & 216012 & 246207 \\
\hline EU (world $=100)$ & $43 \%$ & $30 \%$ & $30 \%$ & $27 \%$ & $29 \%$ & $16 \%$ & $17 \%$ \\
\hline $\begin{array}{l}\text { Dynamics (previous } \\
\text { year }=100 \text { ) }\end{array}$ & 146,9 & 64,2 & 65,9 & 105,7 & 127,8 & 44,0 & 114,0 \\
\hline \multicolumn{8}{|c|}{ Value of greenfield FDI projects by destination (mln USD) } \\
\hline World & 880832 & 1413540 & 1008273 & 860905 & 902365 & 613939 & 672108 \\
\hline European Union & 216647 & 307460 & 194248 & 161758 & 172635 & 133181 & 121601 \\
\hline EU (world $=100$ ) & $25 \%$ & $22 \%$ & $19 \%$ & $19 \%$ & $19 \%$ & $22 \%$ & $18 \%$ \\
\hline $\begin{array}{l}\text { Dynamics (previous ye- } \\
\qquad a r=100)\end{array}$ & 96,7 & 141,9 & 63,2 & 83,3 & 106,7 & 77,1 & 91,3 \\
\hline \multicolumn{8}{|c|}{ Value of cross-border M\&As by economy of seller (mln USD) } \\
\hline World & 1045085 & 626235 & 285396 & 349399 & 556051 & 331651 & 348755 \\
\hline European Union & 533185 & 260664 & 119344 & 118328 & 185332 & 128630 & 120813 \\
\hline EU (world $=100$ ) & $51 \%$ & $42 \%$ & $42 \%$ & $34 \%$ & $33 \%$ & $39 \%$ & $35 \%$ \\
\hline $\begin{array}{l}\text { Dynamics (previous ye- } \\
\qquad \text { ar }=100 \text { ) }\end{array}$ & 160,0 & 48,9 & 45,8 & 99,1 & 156,6 & 69,4 & 93,9 \\
\hline
\end{tabular}

Source: UNCTAD, World Investment Report 2014..., op. cit., p. 213-221.

The more detailed analysis of data allows for the assumption that the level of development of individual economies of the Union no longer indicates of their investment attractiveness. For instance the unquestioned leader among EU states is United Kingdom, which increased its share in the global inflow of greenfield investments by more than 3 percentage points in comparison to 2006. The average value of investments conducted in 2007-2013 was more than USD 39.6 billion. Further positions are occupied by Germany, with an 
average of USD 19 billion, Spain - USD 17.6 billion, and Poland with an average of USD 16.3 billion invested. The highest variability of greenfield investments inflow in the analysed period was observed in Lithuania, Portugal, Greece, and Belgium. Among the EU states, Bulgaria seems to be the biggest loser in the ground-up investment market, with its share in the global inflow of investments decreasing by more than 1.5 percentage point compared to 2006. A relatively large decrease in greenfield investments in the analysed period was also observed in the Czech Republic, Slovakia, Romania, France and Portugal ${ }^{13}$.

TNCs value stable legal conditions ${ }^{14}$, that is, they want to be certain that the conditions they found acceptable at the decision stage will not change during the functioning phase. The stability of law is appreciated when it is favourable for investors. Otherwise, corporations may exert some pressure in order to change the existing regulations. Opening economies to the flow of capital is a primary, although insufficient, factor guaranteeing FDIs. Numerous studies stress that a significant meaning for creating a so-called good investment climate lies in the quality of institutions ${ }^{15}$. Most popular institutional tools for attracting transnational corporations include: tax exemptions, free trade agreements, agreements on avoiding double taxation, international agreements promoting integration, including bilateral investment agreements.

As shown in the above analysis, the 2007-2009 crisis manifested itself also in the capital flow market. The turmoil in the financial market on the one hand and a definite decrease of EU's share in the inflow of foreign investments on the other - these became a stimulus for introducing appropriate institutional changes also in EU states. However, it must be noted that the average number of changes in regulations concerning FDIs has decreased since 2008, globally ${ }^{16}$.

The spreading internationalization of TNCs activities leads them to support multilateral agreements liberating the flow of FDIs. The main change in this area in the EU was introduced by the Treaty of Lisbon, which extended the exclusive competences of the Union in terms of common trade policy also in respect of foreign direct investments. By accepting the Treaty (1 De-

${ }^{13}$ UNCTAD, World Investment Report 2013..., op. cit., p. 226; UNCTAD, World Investment Report $2014 \ldots$, op. cit., p. 218.

${ }^{14}$ K. Bobińska, op. cit., p. 100.

15 See: F.A. Ali, N. Fiess, R. MacDonald, Do Institutions Matter for Foreign Direct Investment?, „Open Economies Review”, Vol. 21, No. 2/2010, p. 206-207.

16 The average number of regulations introduced in 2008-2012 was fewer than 85 , while in 2003-2007 it was around 120. Source: UNCTAD, World Investment Report 2013..., op. cit., p. 92 . 
cember 2009), the European Union significantly increased its authority in the process of negotiating investment treaties, at the same time limiting this capacity for individual states. Simultaneously, the European Commission decided that in order to avoid any legal uncertainty in terms of both EU investors abroad, as well as investments and foreign investments in the EU, there should be a period of transition. During the transition period, the bilateral investment treaties (BITs) entered into previously would still be in effect, that is until they are replaced by the Union's agreements on the same subject. In general, these treaties are supposed to provide EU states with specific warranties concerning the treatment of their investors in third countries, as well as the treatment of third country investors in the EU. These warrants protection of investment in the said agreements form an important element in building trust in legal security, necessary for successful investment decisions. Therefore these types of agreements are considered an efficient method of promoting and attracting investments.

According to the World Investment Report 2013, most of EU's recently initiated negotiations involve protection and liberalization of investments ${ }^{17}$. Because all new EU-wide investment treaties are ultimately supposed to replace bilateral investment agreements between EU states and third parties, these negotiations will contribute to a consolidation of the so-called system of international investment agreements (IIAs). For example, on 25 March 2013, the EU and Japan officially entered into negotiations on a free trade agreement. Both parties aim to conclude an agreement covering a gradual and reciprocal liberalization of trade in goods, services, and investment flow, as well as establish rules on trade-related issues ${ }^{18}$. At the EU-Canada summit on 26 September 2014 were announced the end of talks on the Comprehensive Economic and Commercial Agreement (CETA). These activities are contributing to a consolidation of the relations of particular states as a group, and with third countries. It therefore seems plausible to say that any and all methods of improving the investment conditions in particular member states result from the use of investment incentives and support programmes by their administrations.

The lack of restrictions in capital flow allows companies to choose such an investment location that would be most profitable, thanks to the avoidance of multiple taxation of investment income, and in the case of single taxation - due to lowest possible effective charges. EU states post-2009 have become relatively active in terms of concluding the so-called double taxation treaties

17 Ibidem, p. 104.

${ }^{18}$ Ibidem. 
(DDTs), which avoid double taxation. In 201140 out of 51 concluded DDTs involved EU states ${ }^{19}$. Some of these were signed between EU member states, others concerned relations with third countries.

A relatively significant element of institutional changes introduced after the crisis revolve around taxation rules. Great Britain agreed to reduce the corporate income tax by 1 percentage point annually, from 28\% in 2010 to $24 \%$ in $2014^{20}$. In 2010 , the Hungarian government undertook to introduce a unified corporate income tax rate of $10 \%$ by $2013^{21}$. In 2012, Sweden reduced its corporate income tax to $22 \%{ }^{22}$. In 2013, France introduced a tax exemption in order to promote competitiveness and create new jobs. This exemption aims at increasing investments, research, innovations, trainings, employment, enhance the search for new markets and help companies to regain their financial capital ${ }^{23}$. In 2011, Italy passed an ordinance which facilitated investments and provided tax exemptions for $\mathrm{R} \& \mathrm{D}$, among other things. It also covered the improvement of administrative procedures for companies making tenders in public projects ${ }^{24}$. Among other improvements introduced for companies, it is worth to point Estonia's novelization of its commercial code, which allows the establishment of limited liability companies without the required minimal capital, after meeting certain conditions. This novelization involves both domestic and foreign businesses ${ }^{25}$. In June 2011 Poland adopted the "Programme for supporting investments of significant importance to the Polish economy for 2011-2020", which aims at promoting foreign investments in high-tech industries.

It must be noted that the changes introduced in EU member states after the financial crisis were not always meant be favourable for conducting business in a given territory. Among the changes that limited (restricted) TNCs activities were actions related to abolishing tax exemptions, increasing tax rates (e.g., Slovakia), or regulations concerning the functioning of foreigners

${ }^{19}$ Compiled on the basis of: UNCTAD, Investment Policy Monitor. A Periodic Report by the UNCTAD Secretariat, No. 5/2011, p. 6; UNCTAD, Investment Policy Monitor. A Periodic Report by the UNCTAD Secretariat, No. 6/2011, p. 6-7; UNCTAD, Investment Policy Monitor. A Periodic Report by the UNCTAD Secretariat, No. 7/2012, p. 5.

${ }^{20}$ UNCTAD, Investment Policy Monitor. A Periodic Report by the UNCTAD Secretariat, No. 3/2010, p. 5.

${ }^{21}$ UNCTAD, Investment Policy Monitor. A Periodic Report by the UNCTAD Secretariat, No. 4/2011, p. 4.

${ }^{22}$ UNCTAD, Investment Policy Monitor. A Periodic Report by the UNCTAD Secretariat, No. 9/2013, p. 5.

${ }^{23}$ Ibidem.

${ }^{24}$ UNCTAD, Investment Policy..., op. cit., No. 5/2011, p. 5.

${ }^{25}$ UNCTAD, Investment Policy..., op. cit., No. 4/2011, p. 4. 
in a given country (e.g., Hungary). However, it seems that due to the reduced post-crisis interest in locating TNCs investments in EU states, most of the member countries are presenting a rather liberal tendency in regulations.

Although the Union's objective is to promote a homogeneous market model, also as a place for locating TNCs, it seems neither possible nor desired to completely strip individual member states of instruments of institutional competitiveness. All efforts made in order to promote investments by member states are accepted, as long as they conform to the common trade policy and are consistent with EU's law. The considerations in this section demonstrate the diverse character of actions undertaken by European countries in terms of FDIs. Some of the introduced regulations are characterised by liberating capital flows, others yet are more restrictive.

\section{CONCLUSION}

The last financial crisis has greatly limited the flows of capital on an international scale. Also, the direction of their transfers has also changed. Developed countries, and European Union member states in particular, have manifested a decrease of their share most prominently in direct investments. This type of investments, however, is considered an important form of TNCs expansion.

The title of this study presents a conclusion to the conducted analyses. They have shown that the institutional changes introduced in the European Union, as well as in individual member states, are supposed to be favourable to location decisions of transnational corporations. The unification of policy concerning investment treaties, conclusion of anti- double-taxation treaties, decrease of the corporate income tax rate, tax exemptions - all these greatly improve the investment attractiveness of economies.

However, it must be noted that for TNCs it is important that the common international investment policy allowed not only the realisation of direct investments only, that is, the purchase of foreign companies of establishment of ground-up investments, but also that it protected all the actions accompanying such investments, like payments, transfer of profits, security of intangible assets, such as intellectual property rights. 


\section{BIBLIOGRAPHY}

Ali F.A., Fiess N., MacDonald R., Do Institutions Matter for Foreign Direct Investment?, „Open Economies Review”, Vol. 21, No. 2/2010, http://dx.doi. org/10.1007/s11079-010-9170-4.

Bobińska K., Od niekontrolowanej globalizacji do zinstytucjonalizowanej gospodarki światowej, Key Text, Instytut Nauk Ekonomicznych PAN, Warszawa 2009.

Gasz M., Znaczenie korporacji transnarodowych w gospodarce światowej, „Ekonomia i Prawo", Vol. XI, No. 4/2012, http://dx.doi.org/10.12775/eip.2012.031.

Kluzek M., Znaczenie konkurencji podatkowej dla rozmieszczenia bezpośrednich inwestycji zagranicznych w Unii Europejskiej, Wydawnictwo Uniwersytetu Ekonomicznego w Poznaniu, Poznań 2012.

Piórko K., "Wtadza” korporacji transnarodowych w stosunkach międzynarodowych, Wydawnictwo Naukowe Grado, Toruń 2008.

UNCTAD, Investment Policy Monitor. A Periodic Report by the UNCTAD Secretariat, No. 3/2010.

UNCTAD, Investment Policy Monitor. A Periodic Report by the UNCTAD Secretariat, No. 4/2011.

UNCTAD, Investment Policy Monitor. A Periodic Report by the UNCTAD Secretariat, No. 5/2011.

UNCTAD, Investment Policy Monitor. A Periodic Report by the UNCTAD Secretariat, No. 6/2011.

UNCTAD, Investment Policy Monitor. A Periodic Report by the UNCTAD Secretariat, No. 7/2012.

UNCTAD, Investment Policy Monitor. A Periodic Report by the UNCTAD Secretariat, No. 9/2013.

UNCTAD, World Investment Report 1993. Transnational Corporations and Integrated International Production, United Nations, New York 1993.

UNCTAD, World Investment Report 2005. Transnational Corporations and the Internationalization of REDD, United Nations, New York, Geneva 2005.

UNCTAD, World Investment Report 2009. Transnational Corporations, Agricultural Production and Development, United Nations, New York and Geneva 2009.

UNCTAD, World Investment Report 2013. Global Value Chains: Investment and Trade for Development, United Nations, New York, Geneva 2013.

UNCTAD, World Investment Report 2014. Investing in the SDGs: An Action Plan, United Nations, New York, Geneva 2014. 